\title{
Changes in the Economic and Social Structure and Alternatives of the Economic Policy in Russia \\ ロシアにおける社会・経済構造の変化と経済政策の選択
}

はじめに

ロシアでは、1995年後半期にはGDPの低下が止 まり底を打ち 96 年からのプラス成長がOECDなど によって予測されたにもかかわらず、96年1-9月 GDPは一6\%で、とくに投資の低下幅が大きく、96年 8月時点の受注水準が改善していないために悲観 的な見通しが多い。この経済状況は、1993年に底 を打ち経済回復が続き「移行期」が終わったとさえ 言われる中東欧と区別される。EBRDの95年GDP 成長率の推計值はチェコ $5.2 \%$ 、ハンカリリー $2 \%$ 、ポ ーランド $7 \%$ 、スロヴァキア $6.6 \%$ 、スロヴェニア $5.1 \%$ \%あるそれゆえ、ロシア、東欧に現れてい る「共産党の復権」では、資本主義への移行および 世界分業への包椇過程の困難さは移行諸国間に共 通しているが、経済回復状況および復権によって 期待される経済システム像は相互に異なっている ように思われる。

本稿の課題は、ロシアにおける「共産党の復権」 の社会・経済的背景と復権過程で模索される経済 政策を分析して、ロシアの市場移行過程の現状を 明らかにすることである。つまり、「共産党の復権」 を足掛かりにして、次のふたつの問題をここでは 検討しよう。

第1に、共産党が1995年の総選挙で支持を得、 96年大統領選挙で一定程度の支持を受けながら最 終的にエリツィンに逆転されるに至った選挙結果を 生みだすロシアの社会・経済的背景とはどのよう なものか、言い換えれば資本主義経済への移行過 程に入って5年程にどのような変化が生じているの か。本稿では、ロシアと中東欧との改革に対する 国民の温度差を明らかにするために、この問題を、 地域およびミクロ (winnerとloser) 面での変化、移 行過程で形成されるエリートあるいは利害集団の 特質に注目する。

第2に、共産党を中心とする人民愛国派 $\Gamma$. ジュ
京都大学溝 端 佐登史

ガノフの経済政策と $\mathrm{B}$. エリツィンの経済政策の間 にはどの程度の開き、共通する部分があるのか、 経済政策の選択に関わる問題である。この分析に より今後のロシア経済の見通しを考える。

\section{I. ロシア市場移行における社会・経济輠造の変化} (1)市場化政策の推移

1992年からのロシアの経済政策は一般に「ショッ ク療法」型と言われるが、実際には一貫して安定 化政策が実施されたわけではなく、季節的要因、 国際的支援 (IMFとの合意)、政治的対抗に左右さ れて、マネタリーポリシーに基づいたインフレ抑制 を中心とする安定化政策とその弛緩とポピュリスト 的な政策への転換の間を循環的に変動している。 このような循環は、1992年以来3つの波動を描いて いる。第1波は1992年から93年の安定化が強めら れる時期で、第 2 波は93年から94年央に政府が「シ ヨック療法」を採用しないことを明言し、適度に厳 しい財政・金融政策と選択的な産業政策を提起す る緩和の時期で、第3波は94年秋から95年にかけ て再び安定化政策が採用される時期である。96年 には「経済改革の第1段階は完了した」と見なされ、 税制、投資、国家の役割、産業政策を重視する第4 波に入ったと考えられる。このような循環の結果 をここでは4つの側面一(1)マクロ経済的な側面、(2) 地域経済の側面、(3)経営者などのミクロ経済的な 側面、(4)国家と企業の相関関係の側面一で描き、 共産党の支持が拡大するがそれが旧システムへの 回帰に直結しない意味を探り出そう。

（2）市場移行の実像

一「共産党復権」のマクロ的背景

表1３からインフレ、実体経済、財政、社会政策 および失業問題を確認する。

インフレ率は 95 年 $231 \%$ と高いが、96年に入り 
安定的で、96年上半期の消費者物価は15\%の伸び で、その後も 8 月 $-0.2 \% 、 9$ 月+ $0.3 \%$ と安定的に見 える。このようなインフレ収束傾向に対し、実体経 済面では1990年から95年にGDPが $40 \%$ 下落し、96 年も低下はおさまっていない $(1 \sim 11$ 月にー6\%)。 この実体経済の低下には、(1)産業構造上の格差、 (2)企業の未払いの増加、(3)地域間格差、(4)1996年 に入って実質所得の伸び・消費の伸びおよび住宅 建設の伸びからの楽観的見通し、といった特幑も 検出される。

財政面では、統合連邦予算の財政赤字が10月末 に79兆ルーブルとGDPの4\%水準で、徴税率の低下は 深刻な問題になり(1～9月に墄入計画の71\%徴収)、 10月には税・予算規律強化の臨時非常事態委員会 が設けられている。連邦予算への税の未払い分は 年初の31.5兆ルーブルから6月1日時点の61.3兆ルーブル に倍增している。上半期の歳出不足額 60 兆ルーブル は赤字国債に依拠しており、国債利子払いの膨張 が見込まれており、このような政府の借入は民間 投資を抑制する一因にもなる。1997年の連邦予算 は歳入がGDP比 $15.7 \%$ 、歳出 $19 \%$ 、財政赤字 $3.3 \%$ である。さらに、連邦予算の弱体化は連邦中央と 地方との対抗関係をあらわにし、92年以来国家の 地域支援の措置の半分は実施されないままで推移 している。

社会政策面では、1994－95年に実質傊金、実質 所得、実質年金が低下したが、1995年から96年6月 に名目で74\%、実質で15\%、ドルベースで59\%上 昇し、貯蓄の回復傾向も観察される。こうした家計 レベルでの蓄積は経済的な緊張を和らげる判断材 料である。また、失業に関しては96年11月末時点 で登録 246 万人 $(3.4 \%)$ ，ILO基準実質 680 万人 (9.4\%) で増加率は渐進的であるが、失業者には長 期、特定層への集中の傾向が観察される。ここに は移行過程の経済政策に対する不満と現路線肯定 の両方の意識の存在が暗示される。

国民の意識はマクロ実績を反映する。95年春か ら夏にかけての市場移行に対する住民の世論調査 (3 а сл а в ск а я, T 1995, с т р.9-10.) は、市場化 に否定的な態度が増えていることを示すと同時に、
市場に対する適合層も出現していること、市場の 否定・社会主義への回帰にも否定的であることを 明らかにする。経済実績の悪化を反映して、市場 経済を積極的に支持する層は半減しており、75\% が資本主義化を特定の人々を潤すと見なし、過半 数が移行を支持しているが、主要な支持層は若年 層・私的セクター就業者層で、世代、階層などの諸 集団における市場適合層と非適合層への分裂が明 らかになる。とはいえ、改革の停止の支持は1/4で、 社会主義の復活支持はさらにその半分にすぎず、 社会保障を強める方向での市場化の支持が大き W。

\section{（3）市坦移行と地域间格差}

\section{一「共産党復喍」の地域経济的背景}

ロシアの地域経済の独自性を分析したバーミン カム大学の地域経済研究 (78地域を対象にした地 域分類, Hanson, P.,1996a) は、人口の36\%を占め る43の通常の地域を除いて、特街ある4つの類型 を示し、市場化による利益取得地域・覀失地域と 政治的支持との相関関係を明らかにする。

第1はダゲスタンなど11地域からなる農村地域 で、95年 1 月時点で、農村人口が $45 \%$ 以上を占め る地域である。この地域は総じて改革のloserであ り、それゆえ大統領選では共産党のジュガノフに対 する支持が高い所である。

第2はチュメ二など $8 つ の$ 自然資源地域であり、 燃料、非燃料、金属、木材・同加工部門に属する 地域で輸出上の利益を取得するwinnerであり、改 革継続を支持する。

第3はモスクワなど 13 の商業中心 ·出入口地域 で、1994年時点で外貨取引所、主要な海上貿易施 設を有する地域であり、第4はモスクワ州などエレ クトロニクスや通信機器に基づく R\& D · 㕍用吸収 10地域であり、いずれも市場化の恩恵を取得する winnerであり、概して改革継続を支持する。市場 化に伴うwinnerとloser、経済的な地域間格差が現 れ、それが大統領選挙結果、「共産党の復権」に影 響していると考えられよう。

地域間格差はいくつかの経済指標で表示され 
る。消費者物価に関して、域間取引障壁、輸送コ スト、脆弱なインフラによって地域間で物価水淮は 異なり、1995年末の19品目による消費財バスケット では全国水準の53\% (ウリヤノフスク州)から203\% (サ八共和国) までおよそ4倍の格差が開いている。 地域間の所得格差では、チュメニ州(エリツィン支 持)の所得格差は全国平均よりも大きく、アルタイク ライ(ジュガノフ支持)のそれは全国平均よりも小さ い。なお、連邦中央と地方の間には双方向に対抗 力と援助を求める力が働く。独自の民営化措置や 価格の自由化に対し制限を設ける地域、域外への 物流を制約する地域が存し、こうした地方の対抗 力は国民経済全体への中央の経済政策の浸透力を 抑える。他方で、ソビエト時代の中央に対する地方 の依存度が大きいという事情の惰性から中央の財 政に援助を求める地方の力も強い。94年連邦予算 は地域支援基金を設け、59連邦主体が財政補助を 受け、その数は96年予算では74にのぼる。それゆ え、地域における政治状況 (地方知事選挙)もまた ロシア連邦全体における経済政策に及ぼす影響力 を強めている。

\section{II．市場の経済主体と行的}

\section{一「共産党復権」のミクロ的背景}

\section{(1) 筫本形成}

市場化にともない、ひとつの社会層として共通 利害を有し、政治にも影響力を有する経済エリー 卜集団の像が明確になり、政府の経済政策に対す る彼らの影響力は強くなっている。経済エリートの 中軸はガス、石油、航空宇宙、銀行の4つであり、 これ以外にも圧力団体を通じた産業部門の共通利 害も形成されている。このようなエリート集団は市 場化のなかで輸出産業、競争力を有する産業、 Rent-Seekingを含めて利益機会が大きい集団に相 当する。もっとも、市場化に対応してかれらの行動 が直ちに競争市場での利潤指向型になるわけでは ない。移行直後の1991年から92年に、かれらは独 占的な地位を利用し、また政府補助金あるいは補 助的な扱いを求めてRent-seekingの行動一鞘取り 売買、輸入補助金や補助信用の取得、民営化によ
る資産の取得など一を強める。このような行動は 補助金の廃止や税制改革などで低下し、経済主体 の市場への適合が余儀なくされるが、エリート層は 市場化に適合しながらも、政治に対する影響力を 強め、税の特恵温存や補助の確保など多様な経路 でのRentの確保を図ろうとする。

経済エリートのうち、金融機関の力が1995年以降 強くなっており、とくに銀行の力の拡大には次の2 つのモメントが働いている。

第1に、銀行は資金調達難の国家に対する融資 と95年8月からの担保型民営化によって、直接に outsiderとして企業の所有権を取得するとともに政 府の経済政策に対する影響力を保持した。担保型 民営化は政府の放出する戦略産業企業の株を担保 にして主力銀行が政府に掘資する制度で、銀行間 の競争と銀行と国家の結びつきを示している（銀 行が用いた資金は自己の資金ではなく国家からの 資金であった)。1996年上半期での民営化収入額 は1兆 400億 $ル$-ブルで、4つの投資家（銀行、投資機 関、外国の会社、住民)のうち、銀行および投資機 関が需要の $98 \%$ 以上を占める。この担保型民営化 の対象には表4に示したとおりノリリスク・ニッ片く〈H орильский никель〉、ルークオイル〈ЈУК ○ทั.. 】など石油部門、金属、運輸など競争力を有 する戦略部門の大企業が含まれる。大統領選後 0 Н Э К С И М (オ祊シム) 銀行総裁が入閣したが、こ のことも銀行グループの影響力の大きさを示して いる。この O H Э К C И M銀行は担保型民営化の 中心に位置し、図1はそのネットワークを示してい る。

第2に、金融・産業グループが設立され、巨大資 本の形成が進行している。金融機関と工業企業が 結びついた金融・産業グループは国家の影響を受 けて93年以後に大統領令および政府決定に立脚し て形成され、95年11月下院で法律が採択された。 金融・産業グループは国家の役割を重視する市場 経済化の考え方に支持され、この巨大資本を成長 点と見なすところでは共産党と政府は一致する。 金融・産業グループの利害を代表する13人の代表 者「Group-13」が大統領選に先立ちエリツィンとジ 
ュガノフの妥協を模索した背景には金虽・産業グ ループの政治上の位置が存している。

96年末現在46の公式に登録されたグループがあ り、非公式に集団を構成するもの（ほぼ同数存す る）と区別される $(96$ 年 6 月時点でGDPの $10 \%$ 以 上を占める。うち約半数は模範的なグループで、 95 年に生産高は $5 \%$ 、販売高は $30.9 \%$ 、輸出は $27.3 \%$ 、利潤は $48.3 \%$ 、投資は 2.5 倍上昇している 〈Сегодня〉,19 июн я1996)。グループの中核企 業14社の経営者に対する95年の意識調査では、投 資計画の作成、経営者の選択、参加企業の財務分 析、販売組織化などの効率化措置が半数以上で講 じられているが、グループ内の意思決定には情報 の欠如などの障害も指摘されている。金虽・産業 グループは 94 年に工業生産高の $3 \% 、 95$ 年に $10 \%$ 以上を占め、巨大な金属、自動車企業、大銀行が 含まれ、国民経済に及ぼす影䈉力は大きい。その うえ、非公式の金融・産業グループも設立され、そ れにはカススプロムなど輸出力をもつエネルギー企 業も関与している。金融・産業グループの経済パ フォーマンスは、設備の老朽化と会計制度の未整 備から効率化できない事例も含まれるが、総じて ロシア経済全体の平均に比して高い。表5は公式 型金虽・産業グループの特徴とパフォーマンスを 示している。金融・産業グループの力を示す傾向 を5点あげておこう。

(1)非公式の金融・産業グループは株式の相互持ち 合いや融資などを通じて関係を結び、経済だけ でなく政治にも影䭓力を強めている。

(2)強力な銀行が金虽・産業グループに参加し、金 融機関の再編が進んでいる。

(3)金融・産業グループの地域経済に及ぼす影響力 は強い。金融機関が首都を中心に大都市圈に集 中しているので金融・産業グループも大都市に 集中し、モスクワ市も独自の条例を定めている が、他地域も域内の経済・社会安定化のために グループの誘致を進めている。

(4)金融・産業グループは旧ソ連邦の再統合力が強 まるなかで、当該諸国の経済主体が相互に利害 をすり合わせる基盤になっており、ラトビア、べ
ラルーシ、カザフスタン、ウクライナ、キルギスと の間ではすでに多国籍金融・産業グループが編 成されている

(5)金融・産業グループは閉鎖的な組織ではなく、 グループ間 (銀行間) で相互に結びついて金融・ 産業グループ集団さえ形成する。そのうえ、財界 団体として金融・産業グループ連盟も結成され 影響力は一段と強まっている。

金融機関、金融・産業グループが形成・再編さ れ、巨大資本の姿が桷次明らかになったが、こうし た巨大資本は国民から違法な経済行為の主体と見 なされ、それに対する反発を招くという意味では 金融に対する政府の規制を主張する共産党が支持 される基盤になる。しかし、同時に金融機関はす でにひとつのエリート集団としての形をなし、政治 との間に

も利害の共有性が存する。それゆえ、金蚰機関は 国民の批判を受けつつも、改革を維持する強力な 推進力 (旧システムへの回帰に対する抵抗力)の役 割を果たしており、共産党もまたこの存在を無視 できないし、ひとつの成長基盤として容認する見 方を示している。

\section{（2）企業と労的者の行轨における情性と変化}

ロシアの民営化では、国有企業が株式会社に転 換され、国家が保有する株が放出されたが、株は 主としてmanagement-employees buy-outにより企 業経営のinsider control 化を進めた。しかし、すべ ての企業が変化せず国家の保護を受けたわけでは なく、民営化の当事者間で利害は分散し、民営化 と国家への補助の要求の尺度において企業の行動 は次の4つに区別される。(1)民営化を進めながら 国家への補助・官僚的調整を求める企業 (大企業 に典型的)、(2)民営化よりも政治的な行動を優先す る企業 (軍産複合体や非採算企業)、(3)民営化によ り市場に適合して政治から自立する企業 (企業家 精神に富む中企業)、(4)民営化を進めず政治の発 言力も弱い企業。ただし、資本市場の整備に伴い 大規模な外部投資家の影響力は大きくなっている (表6)。 
企業行動面でも変化と惰性が同時に現れる。市 場移行の初期段階に、企業は部分的には市場に適 合して利潤指向、需要制約、ハードな予算制約を 強めるが、同時に惰性的な経営も行われる。経営 者は集団の維持、労働力の保存を経営目的の上位 にあげ、集団の温存を政府 (中央・地方) からの補 助金・特恵取得の交涉材料に利用する。政府の側 も社会的給付の維持、地域における安定化（㕍用 確保)の観点から補助を維持しようとする。こうし て、企業には市場に適合して変化する力と集団の 温存をはかる惰性が同時に作動する。

企業経営における変化と惰性は、労働者の行動 をも基盤にしている。企業内には労働者と経営者 の集団主義的な関係が作動し、失業を回避する力 が働き、社会的給付の維持が経営の安定化要因と して働く。しかし、企業が政府に援助を求める安 定化要因のコストは市場化にともない高くなり、当 事者の利害は分断する。国家の補助が途絶えると 企業は賃金未払いを膨張させ、㕍用は不安定化し、 労働者の政府、経営者への信頼・支持は低下する。 そのうえ、労働者の利害を代表する労働組合は信 頼性を失い、労働者と団体協約を結ぶ企業の比重 も低下する。新しい私企業には労組も団体協約も 備えない場合が多い。

\section{III.市溃移行への国家の影零力}

国家と企業の補助・温情と自立化の相反する傾 向は資金の流れに投影される。

市場移行の初期段階には、国家から企業への補 助金と企業からの国家への資金の吸い上げは次の ような特性をもって全体として旧システムと同じ水 準で維持された。(1)1992〜1993年に予算外の輸入 補助金、補助的な信用が利用され、企業にとって Rent-seekingの機会となった。(2)明示的補助金に 代わり税の未厸いや信用供与などの隠れた補助金 が大きくなった。(3)政府への売却の大きさと政府 からの移転の取得額の間には相関関係があり、政 府消費は維持された。(4)地方政府からの補助が拡 大し、主として農業および食料品加工、公共輸送 機関、公共施設などが対象になる。
このように、ロシアの市場移行では変化と惰性 の両方が作動し、利害を共有する集団とその関係 が形成された。この利害関係は労働者からエリー ト層までを結びつけて総体として編成され、とくに 労働者の利害を代表する労働組合の権能が失墜 し、資本対労働者の形で当事者の利害が直接に政 党に反映するわけではない。共産党への支持の拡 大と市場化の維持の背景には、ミクロレベルの利 害編成とその独自の行動様式が存している。

\section{IV.ロシアにおける市場移行の経済政策の行方}

では、社会・経済構造の変化に対し、大統領選 挙の当事者はどのような経済政策を選択している のであろうか。大統領選第1ラウンドでは10名の候 補者のうち6名がプログラムを提出し、すべてが経 済学者の手によるものと言われる。選出されたエ リツィンと国民の支持が高くなっている人民愛国派 共産党ジュガノフの経済政策を比較検討してみよ j。

\section{(1)ジュガノフの経済政策}

ジュカノフの経済政策は96年 5月25日付け『独立 新聞」に、11の質問に対する回答の形式で公表さ れ、次いで 5月28日付け『プラウタ」が「社会・経済 プログラムの基本規定：崩壊から創造へ. 21世紀 へのロシアの道」を掲載した。

プログラムはエリッィンの市場化をマネタリズム の中性子爆弾によるカタストロフィー(通貨制約と自 由化が実体経済の危機を招いた)、西側に対する 原料基地化、買収された国家官僚と大独占集団の 経営者の利害の代表と批判したうえで、政策の基 本的な方向性として、混合経済、国内生産者の保 護、国家規制の強化 (金融・産業グループの形成 と三者委員会)、予算政策の修正、農業改革 (価格 均衡化と食糧安全保障)、社会政策 (社会的公正) などをあげている。生産復興の成長点を国内消費 財産業 (軽工業、食品工業)二輸入代替工業化に求 めている点は注目され、そのための方策として特 恵的な信用供与と住民貯蓄の投資への還流を提起 し、三段階の復興過程を描く。(1)1996 98年の国 民に信頼される政権の確立期 (価格均衡や支払い 
危機の解決)、(2)1998～2003年の投資促進と優遇 税制の実施などに基づく高度成長期、(3) 2004 〜 2010年の脱工業化型技術と世界市場への参入期。 プログラムは、保護主義政策、引き締め策から成 長政策への転換、国家の役割の重視と国有セクタ 一の活性化では現政府の経済政策と類似性を有 し、「政府閣僚の $90 \%$ が署名しうる」と評される。 Hanson, P. (1996b)は「ジュガノフの経済政策は口 シアにおけるIMFコンディショナリティ、開放経済、 財政安定化、首尾よい経済のリストラとは両立しが たい。それを別とすれば、政策はきわめて穏健な ものである」と結論付けている。

この経済政策の策定では1991年の改革派経済学 者のT. コリャギナらが中心的な役割を果たしてお り、2種類の経済政策が模範となっている。1933年 のF.D.ルーズベルトのニューディール政策 (介入主 義)と1980年代のソ連邦における第3の道型の経済 改革であり、旧システムへの回帰ではなくケインジ アンの立場が重視され、自由主義的な安定化政策 ではなく国家の役割を重視する点で、政府、エリッ インの政策と重なる度合いが大きい。

\section{(2)エリツィンの経清政策}

エリツィンの経済政策は「ロシア：人間、家族、 社会、国家」と題する1996〜2000年の行動プログ ラムで、1996年 5月31日に公表された3部からなる 大部のものである。このうち、第1部「道の選択」は、 移行過程において市場化の基礎が形成されたが、 経済分野で誤りがあったことなどを指摘する。第2 部「新しい政策の優先性」では、「ロシアは1991年 にシステム危機の袋小路に入り、96年に新しい市 場システム編成の危機を体験している。91年との 対比で95年には消費財市場の飽和、多くの部門で の生産の変動、財政赤字、貿易収支、外貨準備高 などで状況が改善している」という現状認識を明ら かにしたうえで、次の経済政策を提起する。

(1)経済における秩序回復：旧システムの惰性に抗 する際に、自由主義的な市場化政策が無政府性 を招き、国家の当事者能力の欠如と政策決定に おけるポピュリストの影響を伴って、経済政策上
の誤り、改革の痛みの不公平な負担、富の不公 平な配分、予算制度の弛緩が生じた。それゆえ、 国家の役割の見直しが必要となる。

(2)税制改革: 低い徽税率 (脱税) と重税からの生産 への圧力が財政基盤に緊張をもたらしており、 投資を促進する改革 (減税や税体系の見直し) が必要となる。

(3)予算政策：急激な転換は危険で、効率的な予算 コントロール、税制改革、税未納者への厳しい措 置などが必要となる。財政赤字を補填する国債 の発行は長期的には成長を抑えるので、国家借 入の重心を私的外国投資家に移す。

(4)投資プログラムと産業政策：インフレ抑制・貯蓄 増・投資会社への貯蓄の集中、私的投資家・株 主の保護、私的投資の刺激などの投資戦略を実 施する。

(5)小経営の発展

(6)農業改革：真の資産・土地所有者の編成と多様 な農業協同組合形態の発展のため、国内生産者 の保護、農業部門の輸出力の回復などを図る。

上記の政策から、2000年までに新しい市場シス テム形成を達成し、年 $4 \%$ 以上の成長、生産を刺激 する新しい税制、民営化の完了と国家の効率的な 資産管理制度の編成、成長を保証し輸出を促す高 度技術部門への構造転換などが展望されている。 このほか、社会的公正についても、㕍用確保や所 得政策と財産格差水準の引き下げ、年金の引き上 げなどを提案し、法秩序に関しては犯罪の取締り、 官僚の横滑り批判が提起される。

エリツィンの経済政策は安定化政策を緩めること に慎重な態度を示しているか、、(1)投資政策・産業 政策の重視、(2)徽税能力の強化を含む国家の役割 と能力の強化、(3)中小企業の成長を含む雇用対策、 (4)農業面などでの保護主義的な政策、(5)経済成長 を先導する輸出主導部門の成長重視、(6)社会政策 の重視を特徴としてあげることができ、ジュガノフ の経済政策と重複する内容を有している。

\section{（3）大赫領・政府の経済政策䚁測}

ふたつの経済政策を比較して、ジュガノフの政策 
を国家コンセプト、エリツィンの政策をラディカルコ ンセプト(国家の最低限の干涉)と対照的にとらえ ることもできようが、私はふたつの経済政策の間の 類似性に注目したい。とくに、これまでの経済政策 の誤りとして 92 年に開始した「ショック療法」型の 経済政策を批判する点、安定化・インフレ対策に重 心をおいた政策から成長政策へ転換している点は 政府および影響力のある研究機関のシナリオなど にも投影している。

例えば、科学アカデミー国民経済予測研究所は 経済政策の選択肢として市場の自動調節に重心を おく型と国家規制の回復に重心をおく型を比較し、 後者が高い経済成長を導き出すと提言しており、 また数理経済研究所「過渡期経済のマクロ実態」は 92年以後の自由主義的な経済政策下で企業は市場 に適合できなかったと批判し、マクロ・ミクロ両面 での生産・投資・技術革新の活力を引き上げる条 件の整備や経済の国家管理システムの再編を提起 する。さらに、アバルキン (Абалкин,Л.) をはじめ とするロシア科学アカデミー6名の経済学者と Klein, L. などアメリカの5名のノーベル賞受賞経済 学者の手による「共同アピール」は「ショック療法」 型経済政策を批判し、国家の役割の強化、経済犯 罪の防止、安定化政策から不況克服・成長政策へ の転換、社会政策、競争的な企業の創出を提起し ている（『独立新聞』1996年7月1日付け)。これら の見解は、経済政策の重心が成長軌道＝投資源泉 の模索に移動しており、そのために国家の役割が 重視されていることを含意している。以上のような 政策転換の提言は政府の経済政策にも明瞭に反映 している。

96年 8月下院で首相は、インフレ抑制が主要な課 題となる段階が終了し、生産の高揚と効率の引き 上げが第1の課題となる新しい段階が始まってい ると指摘し、経済政策に次の修正を提言する。(1) 国家規制や経済における国家の役割の見直し、(2) 2000年までに1995年に比して14〜15\%のGDPの成 長、(3)住民の実質貨幣所得の安定化と最低生活費 以下の所得階層の縮小、(4)未払い問題の解決、(5) 予算の正常化と税制改革、6国家は企業に直接干
涉しないが、規則や会計、税などを規定する、(7) 選択的な国家支援のメカニズム (輸出奨励部門へ の投資を奖励する課税、技術後進部門への輸入関 税と非関税障壁）、8農業改革 (特恵的な信用) と 社会政策 (5 7 年で社会的支出を $1 / 3$ 増加)。その うえ、1997年度予算でも投資、未払い問題は最重 要課題になっている。

大統領選での政策対立の程度に関わりなく、経 済政策の選択では、厳しい安定化政策の緩和、国 家の規制的役割の重視、産業政策・実体経済の回 復のための政策への傾斜、資本市場の整備などへ の政策転換が生じており、それを支える利害集団 も形成されている。

おわりに

大統領選の背景として、市場移行が生み出した 利益取得者と利益喪失者、その内部での利害の分 裂や国家・企業・労働者間での利害の結びつきが 存しており、それが市場に対する不満と無知から 「共産党の復権」の基盤になるとともに、市場移行 を不可逆的なものとする基盤になっている。とくに、 このような利害形成において注目すべき点は、資 本・銀行が国家と結びついてその影響力を拡張し ていること、市場における国家・企業・労働者の行 動には変化 (市場への適合)と惰性が存しているこ とである。このような移行経済において、ロシア政 府は安定化政策を循環的に弛緩させながらインフ レを抑制してきたが、構造再編・合理化は先送りさ れ、96年の生産後退に直面して政府は投資活性化 と国家の役割の見直し、社会政策の強化を政策の 中心にすえるスタンスに変わり、政治面での安定化 と政策の転換から「経済改革の第1段階」は終了し たと考えることができよう。

ロシアにおける「共産党の復権」は市場化に抗す る力と市場化を進める力の両方が結びついた環境 のなかで現れているが、社会主義システムへの回 帰ではなくロシアにおける独自の市場像、市場化 の特殊性に根ざしている。この特殊性は市場移行 の初期段階での経済政策の動摇とそれに対する経 済主体の次のような反応に投影される。ロシア社 
会の伝統や遭産に立脚して市場化が進化的なもの にならざるをえなくなっていること、マクロ経済面 の変化にもかかわらず企業の市場への適合力には 格差があり、総じて適合力は強くないこと、エリー 卜層の再編では旧システムのエリート層との一定の 連続性が存しており、国家の役割は安定性と信頼 性を欠くことなど。このような特殊性を強調するこ とはジュガノフとエリツィンとの間での経済政策の 対抗軸を不透明なものにし、成長政策への転換、 国家の役割や保護主義的な政策への傾斜など政策 における両者の類似性を際立たせる。大統領選下 での経済政策選択の類似性はロシア市場に形成さ れた資本と国家・労働者との利害の重なりを拠り 所にしており、国家の経済への介入、強い国家の 形成は有効需要創出や市場活性化よりも独占とエ リート層の形成・再生という階級形成過程を強め るように思われる。

（追記）

本稿の作成にあたり1995～96年に客員研究員と して滞在した英国バーミンガム大学ロシア・東欧研 究センターのスタッフ、とりわけJ.Cooper所長、 P.Hanson教授、M.Berry氏に、責重な資料とご助 言をいただたことに対し深く謝意を表したい。 また、学会当日、座長宮本勝浩先生(大阪府立大学)、 討論者吉井昌彦先生 (神戸大学)、さらに一般討論 では多数の会員の方々から貴重なご教示をいただ いた。記して感謝申し上げたい。

本稿に関連して、とくに II および血節の内容に関 し、下記の拙稿を参考にされたい。

\section{一考文献一}

Hanson, P. ( 1996a) Russia's Regions, The Mysteries of the 89 Organisms, paper presented at the Annual Conference of BASEES, Fitzwilliam College, Cambridge, 30 March-1 April, 1996, U.K. Hanson, P. (1996b) Russia: Zyuganov's Economic Programme.

Заславская,Т. (1995) Человек в реформируемом Российском обшесте, 〈Обшество и экономика), № 9.
Mizobata, S. (1995) Formation of Financial Capital in Russia: The Reality of Financial-industrial Groups and Comparison with Japanese Model, KIER Discussion Paper, No.429.

清端佐登史（1996a）『ロシア経済・経営システム研 究」法律文化社。

㴗端佐登史（1996b）「ロシアの体制転換における 企業と市場一経済主体・行動・動機の惰性と転換」 KIER Discussion Paper, 9602.

Mizobata, S. (1996c) What Kind of Capitalism in Russia?, paper presented for the CREES Annual Conference, Windsor Great Park, U.K., 21-23 June 1996.

Mizobata, S. (1996d) Transforming Enterprises in Russia, KIER Discussion Paper, No.444. 
表1 ロシアの経済実績 1992〜1996年（年間の変化：\%）

\begin{tabular}{|c|c|c|c|c|c|}
\hline & 1992年 & 1993年 & 1994年 & 1995年 & 1996年上半期 \\
\hline 実質GDP(2) & -15 & -9 & -13 & -4 & $-5^{(1)}$ \\
\hline 非国家杓夕-(\% of GDP) & & 52 & 62 & 72 & $60^{(3)}$ \\
\hline 工業生産高 & -18 & -15 & -21 & -3 & $-8-10$ \\
\hline 農業生産高 & -9 & -4 & -12 & -8 & -7 \\
\hline 穀物収穫高（100万ト） & 99.3 & 84.6 & 81.3 & 63.5 & 69 (推計) \\
\hline $\begin{array}{l}\text { 投資 } \\
\text { 小売価格 }\end{array}$ & -40 & -12 & -24 & -13 & -14 \\
\hline 一年平均变化 & 2,509 & 840 & 215 & 131 & $22^{(3)}$ \\
\hline 一月平均変化 & 31.2 & 20.5 & 10.0 & 7.2 & $1.9^{(4)}$ \\
\hline $\begin{array}{l}\text { 連邦予算赤字(\% of GDP) } \\
\text { 失業率(\%) }\end{array}$ & 13.8 & 10.4 & 10.4 & 2.9 & 7.1 \\
\hline 一登録失業者数 & 0.8 & 1.1 & 2.1 & 3.2 & 3.6 \\
\hline - ILO基準実質 & 5.6 & 5.7 & 7.1 & 8.2 & 8.9 \\
\hline 輸出(non-CIS) & -17 & +9 & +11 & +25 & +1 \\
\hline 輸入(non-CIS) & -17 & -12 & +8 & +12 & +1 \\
\hline 年平均為替 $-卜$ (R/\$) & 222 & 933 & 2,205 & $4,562^{(5)}$ & $5,097(6 月)$ \\
\hline
\end{tabular}

<注〉

（1） OECDは+2\%を予測し、EBRDは96年-3\%、97年+3\%を予測。

(2) Goskomstat revised series.

(3) EBRDの見通し。

(4) 6月のイフフ率 $1.2 \%$

（5）上半期のルーブルの変動幅(corridor)は 1 \$=R4,550-5, 150で、7月 1日に新しいルールが発効 し、変動幅はR5,000-5,600になった。このルール下で、変動幅は日々600川-ブルの幅を維持して 変動する"crawling band"となった。年末までに変動幅はR5,500-6,100に切り下げられた。

〔出所】

Russian official statistics (by Prof. Julian Cooper in CREES of The University of Birmingham).Russian Economic Trends, 16 July 1996. Izvestiya, 5 July 1996. Finansovie Izvestiya 6 August 1996. Financial Times, 4 November 1996. 
表2１996年ロシアの経済実填および予測值(1)（単位 : \%)

\begin{tabular}{|l|rrrrrr|}
\hline & $1-6$ 月 & 7月 & 8月 & 9 月 & 10 月 & 1996年 \\
\hline GDP & -5 & 1 & -3 & -1 & 2 & -9 \\
工業生産高 & $-8^{(2)}$ & 0.2 & 2 & 1 & 5 & -8 \\
消費者物価 & 15.5 & 0.7 & -0.2 & 0.3 & 1.5 & 20 \\
卸売物価 & 14.5 & 1.2 & 1.1 & 1.0 & 1.1 & 22 \\
小売商品取引高 & $-3.7^{(4)}$ & 2 & 7 & 0 & -1 & -2 \\
実質賃金 & $15^{(5)}$ & 2.6 & 0.3 & 2.6 & 1.4 & 17 \\
輸出 (non-CIS) & 1 & -16 & 6 & 6 & 0 & 3 \\
輸入 (non-CIS) & 1 & 16 & -11 & 3 & 5 & 5 \\
登録失業者数 & $10.2^{(6)}$ & -1.8 & -0.4 & -2.8 & -1.6 & 4.7 \\
\hline
\end{tabular}

$<$ 注 $>$

（1）1-6月は対前年同期比 7月は対前月比で、8月以降は予測対前月、対前年比。予測の原出所は経済 大学マク口経済研究・予測研究所。

（2）1-5月の実績値で、対年初比。同じ条件でのGDP実績はー7\%

(3) すべて実續値。

（4）1-5月の実績で、対年初比。

（5）1-6月については6月の実績で対前年同月比。

（6）1-5月の登録失業者数の変化で、対年初比。

〔出所〕

Finansovie Izvestiya, 6, 15 August, 3, 10 September 1996, Delovoi Mir, 6-12 September 1996. Ekonomika i Zhizn. No.35, 1996. Russian Economic Trends, 16 July 1996. 
表3 住民の所得および生活水準（対前年比:\%、R:Uープル）

\begin{tabular}{|c|c|c|c|}
\hline & 1994年 & 1995年 & 1996年6月 \\
\hline 月平均賃金額 & 376(R2 1 7.830) & $219(\mathrm{R} 482,217)$ & 174(R835,000) \\
\hline 実質儥金 & 92 & 74 & 115 \\
\hline 月平均年金額 & $385(R 74,695)$ & 242(R183.533) & $171(\mathrm{R} 313,300)$ \\
\hline 実質年金 & 94 & 81 & 108 \\
\hline 1人あたり 月最低生活費 & $421(R 86,564)$ & 305(R264,100) & 146(R385.100) \\
\hline 最低生活費以下住民数 & 80(人口比25\%) & $110(29 \%)$ & (23\%) \\
\hline \multicolumn{4}{|l|}{ 所得内訳(\%) } \\
\hline 賃金 & 46.4 & 39.5 & 43.6 \\
\hline 社会的移転 & 17.4 & 16.7 & 13.8(推計) \\
\hline 財産収入 & 4.3 & 5.2 & 6.0 \\
\hline 企業活動収入 & 31.9 & 38.6 & 36.6 \\
\hline
\end{tabular}

〔出所〕

Ekonomist, 5.1996. pp.63-64. Finansovie Izvestiya, 3 September 1996.

Ekonomika i Zhizn, No.32, 1996, Russian Economic Trends 1996, V.5, N.2. 
表4 担保型民営化オークション結果

\begin{tabular}{|c|c|c|}
\hline 対象企業 & オークション落札者 & 信用供与総額 \\
\hline スレグトネコチェガス(Surgutneftegaz) & Surgutneftegaz & 4000億ルーブル \\
\hline 北西海洋汽船(Severo-Zapadnoe -..) & 国際金融会社(MFK) & 605万ドル \\
\hline 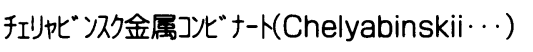 & 北“ J4(Rabikom) & 133万ドル \\
\hline 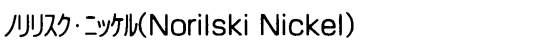 & 才祊厸(ONEKSIMbank) & I 億7000万ドル \\
\hline ル-クォ仪(LUKoil) & ルークオイルーイヘンヘ・リアル銀行 & 3501万ドル \\
\hline 汐冮(Sidanko) & MFK+ONEKSIMbank & 1 億3000万ドル \\
\hline ヴ抄ヘ・リ 金属コビナート(Novolipetskii …) & ONEKSIMbank+MFK & 3100万ドル \\
\hline 山Uマ久久海洋汽船(Murumanskoe …) & 자污ク(STRATEG) & 412.5 万ドル \\
\hline 1 גב(Yukos) & ラグナ+メナテプ銀行 & 1 億5900万ドル \\
\hline 新ロシア海洋汽船(Novorossiiskoe $\cdots$.) & 新口沢 海洋汽船十トコバンク & 2265万ドル \\
\hline †フタ-モスクワ(Nafta-Moscow) & ナフタ-モスクワ+エーニ゙ス銀行 & 2001 万ドル \\
\hline 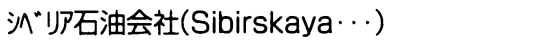 & 首都貯蕃銀行＋石油金融会社 & I億30万ドル \\
\hline 全予算への収入額 & 6億9144. & ＋4000億ルーブル \\
\hline
\end{tabular}

<注〉

国有下の株を担保にとつたロシア政府の融資権に対する競売は 1995年8月31日付け大統領令No.889 「1995年連邦所有の株の担保としての譲渡手続きについて」にしたがって実施された。担保競売に付され る企業リストは9月末に国家資産管理委員会(GKI)が定めた。財務省、GKI、RFFI、その他の部門省庁の代 表者を含めた特別競売委員会は放出株数、当初信用規模、競売実施期間およびその追加的な条件を定め た。競売落札者は政府への貸付と引き換えに株主総会での発言権とともに担保としてロシア企業の株を取 得する。1996年 9月 1日現在、競売落札者と国家との間で貸付と担保の契約期間が満了となった。

【出所】

Л.Сборов, 《Коммерсантъ》,No.34, 1996, p.43. 
表5 ロシアの主要公式金触・産業グループの1994 95年の実统と特徵 (1)

\begin{tabular}{|c|c|c|c|c|c|c|c|c|c|}
\hline 名 & $\begin{array}{c}\text { 生産高 } \\
1994=100\end{array}$ & $\begin{array}{c}\text { 販売高 } \\
1994=100\end{array}$ & $\begin{array}{c}\text { 輸出高 } \\
1994=100\end{array}$ & \begin{tabular}{|l} 
利潤総額 \\
$1994=100$
\end{tabular} & 統合の型 & $\left|\begin{array}{|}\text { メンハー総数 } \\
\text { (う5:工業,金镱 }\end{array}\right|$ & \begin{tabular}{|l|} 
定款資本 \\
(総額 10 傹儿 \\
- 灭 中心企 \\
業の比重\%)
\end{tabular} & $\begin{array}{l}\text { 投資額 } \\
(10 \text { 供しーフル) }\end{array}$ & $\begin{array}{l}\text { 従業員数 } \\
(1,000 \text { ) }\end{array}$ \\
\hline $\begin{array}{l}\text { [Aグループ } \\
1 . \text { Shibir' }\end{array}$ & 107.8 & 172.8 & 7.2倍 & 155.0 & 水平 & $\begin{array}{c}16 \\
(5.5)\end{array}$ & $\begin{array}{r}25.0 \\
63.0 \%\end{array}$ & 1306.4 & 5.9 \\
\hline 2.OGMK & 110.1 & 110.0 & 131.2 & 102.3 & 垂直 & $\begin{array}{c}9 \\
(5,1)\end{array}$ & $\begin{array}{r}14.3 \\
21.0 \%\end{array}$ & 2079.0 & 94.5 \\
\hline $\begin{array}{l}\text { 3.Nosta-Trubui } \\
\text {-Gaz }\end{array}$ & 108.6 & 120.7 & 105.7 & 93.1 & 垂直 & $\begin{array}{c}6 \\
(3,2)\end{array}$ & $\begin{array}{r}9.9 \\
1.0 \%\end{array}$ & 403.8 & 57.5 \\
\hline $\begin{array}{l}\text { 4. Nizhegorodkie } \\
\text { Avtomobili }\end{array}$ & 113.3 & 2.6倍 & 100.5 & 3.2倍 & 垂直 & $\begin{array}{c}31 \\
(21.7)\end{array}$ & $\begin{array}{r}104.7 \\
1.7 \%\end{array}$ & 2437.5 & 215.7 \\
\hline 5.Primorie & 141.2 & 130.8 & 130.0 & 160.0 & 垂直 & $\begin{array}{c}21 \\
(10.4)\end{array}$ & $\begin{array}{l}10.2 \\
9.8 \%\end{array}$ & 1939.1 & 8.7 \\
\hline $\begin{array}{l}\text { 6.Magnitogors- } \\
\text { kaya Stal' }\end{array}$ & 121.6 & 2.8倍 & 119.0 & 197.5 & 垂直 & $\begin{array}{c}19 \\
(13.4)\end{array}$ & $\begin{array}{r}155.9 \\
30.5 \%\end{array}$ & 2603.4 & 152.0 \\
\hline $\begin{array}{l}\text { 7.Volzhsko- } \\
\text { Kamskaya }\end{array}$ & 108.3 & 2.3倍 & 106.7 & 190.0 & 水平 & $\begin{array}{c}3 \\
(2,1)\end{array}$ & $\begin{array}{r}81.9 \\
12.1 \%\end{array}$ & 19693.0 & 198.2 \\
\hline $\begin{array}{l}\text { 8.Metallo- } \\
\text { Industriya }\end{array}$ & 115.2 & 116.6 & 107.7 & 160.0 & 垂直 & $\begin{array}{c}13 \\
(11.1)\end{array}$ & $\begin{array}{r}685.6 \\
0.1 \%\end{array}$ & 1128.1 & 170.5 \\
\hline Aグレープ平均 & 118.9 & 146.4 & 112.7 & 157.6 & $\begin{array}{l}\text { 垂直 } \\
75 \%\end{array}$ & $\begin{array}{c}15 \\
(9,3)\end{array}$ & $\begin{array}{r}135.9 \\
7.4 \%\end{array}$ & 3948.8 & 112.8 \\
\hline $\begin{array}{l}{\left[\mathrm{B} \zeta^{*} \|-\mathrm{J}^{*}\right]} \\
\text { 1.Dragotsennosti } \\
\text { Urala }\end{array}$ & 64.7 & 64.1 & 107.0 & 41.5 & 垂直 & $\begin{array}{c}9 \\
(4,3)\end{array}$ & $\begin{array}{r}5.3 \\
18.9 \%\end{array}$ & 268.8 & 2.7 \\
\hline 2.Interros & 74.9 & 93.5 & 124.9 & 148.1 & 水平 & $\begin{array}{c}25 \\
(6,4)\end{array}$ & $\begin{array}{r}213.9 \\
3.0 \%\end{array}$ & 1986.0 & 21.9 \\
\hline $\begin{array}{l}\text { 3.Vostoch'no Sib- } \\
\text { irskaya Gruppa }\end{array}$ & 101.1 & 102.0 & 3.7倍 & 145.2 & 水平 & $\begin{array}{c}25 \\
(16.2)\end{array}$ & $\begin{array}{l}238.3 \\
42.0 \%\end{array}$ & 1135.8 & 38.7 \\
\hline $\begin{array}{l}\text { 4.Skorostnoi } \\
\text { Flot }\end{array}$ & 95.1 & 103.5 & 73.5 & 108.6 & 垂直 & $\begin{array}{c}18 \\
(6,3)\end{array}$ & $\begin{array}{r}155.5 \\
0.8 \%\end{array}$ & 629.1 & 100.5 \\
\hline 5.Eksohim & 101.0 & 95.2 & 160.0 & 49.6 & 水平 & $\begin{array}{c}22 \\
(15.1)\end{array}$ & $\begin{array}{l}49.8 \\
0.9 \%\end{array}$ & 50.4 & 45.5 \\
\hline 6.Evrozoloto & 71.0 & 65.5 & 6.2 & 40.0 & 垂直 & $\begin{array}{c}8 \\
(3,2)\end{array}$ & $\begin{array}{r}3.1 \\
38.7 \%\end{array}$ & 7584.3 & 2.2 \\
\hline 7.Prompribor & 101.8 & 102.2 & 100.0 & 114.4 & 水平 & $\begin{array}{c}22 \\
(16.2)\end{array}$ & $\begin{array}{r}127.1 \\
1.2 \%\end{array}$ & 116.4 & 21.7 \\
\hline Bグループ平 & 87.4 & 93.1 & 2.1倍 & 111.2 & $\begin{array}{l}\text { 水平 } \\
57 \%\end{array}$ & $\begin{array}{c}18 \\
(9,2)\end{array}$ & $\begin{array}{r}113.2 \\
14.1 \%\end{array}$ & 1681.5 & З3.3 \\
\hline
\end{tabular}

$<$ 注>

（1）Aグル-プは生産高と販売高が顕著に増加したグル-プを含み、Bグル-プは基本的な量指標が低下するか 安定的なグル-プを含む。

(2) OGMK はObedinennaya Gorno-Metallugichesukaya Kompaniya.

[出所】

Ю Винслав, Э.Гуськов, Факторы и пути пути повышения эффективности работы отечественных финансово-промышленных групп, 《Российский экономческий журнал》, №.7,1996, стр.22-23. 
ロシアにおける社会・経済構造の変化と経済政策の選択

表 6 株式会社における所有者別株主分類（1994～1995年定欶買本にたいする比率:\%)

\begin{tabular}{|l|ccccc|}
\hline & $\begin{array}{c}1994 \text { 年 } \\
4 \text { 月 }\end{array}$ & $\begin{array}{c}1994 \text { 年 } \\
12 月\end{array}$ & $\begin{array}{c}1995 \text { 年 } \\
\text { 3月 }\end{array}$ & $\begin{array}{c}1995 \text { 年 } \\
6 月\end{array}$ & $\begin{array}{c}\text { 1996年 } \\
\text { 6月推定) }\end{array}$ \\
\hline イササダー計 & 62 & 60 & 60 & 56 & 51 \\
従業員 & 53 & 49 & 47 & 43 & 35 \\
経営者 & 9 & 11 & 13 & 13 & 16 \\
アウトサイダ一計 & 21 & 27 & 28 & 33 & 45 \\
大規模 & 11 & 16 & 17 & 22 & 32 \\
小規模 & 10 & 11 & 11 & 11 & 13 \\
政府 & 17 & 13 & 12 & 11 & 4 \\
\hline 合計 & 100 & 100 & 100 & 100 & 100 \\
\hline
\end{tabular}

[出所]

ロシア連邦国家資産管理委員会テータ（А.Радыгин, В.Гутник, Г.Мальгинов, Постприватизационная стрчктура акционерного капитала и корпоративный контроль:”контрреволюшия управляюших“?, 《Вопросы экономики》№.10, 1995,cтр.53.) 


\section{図1 ONEKSIM bankの箱造と関係（1995年）}

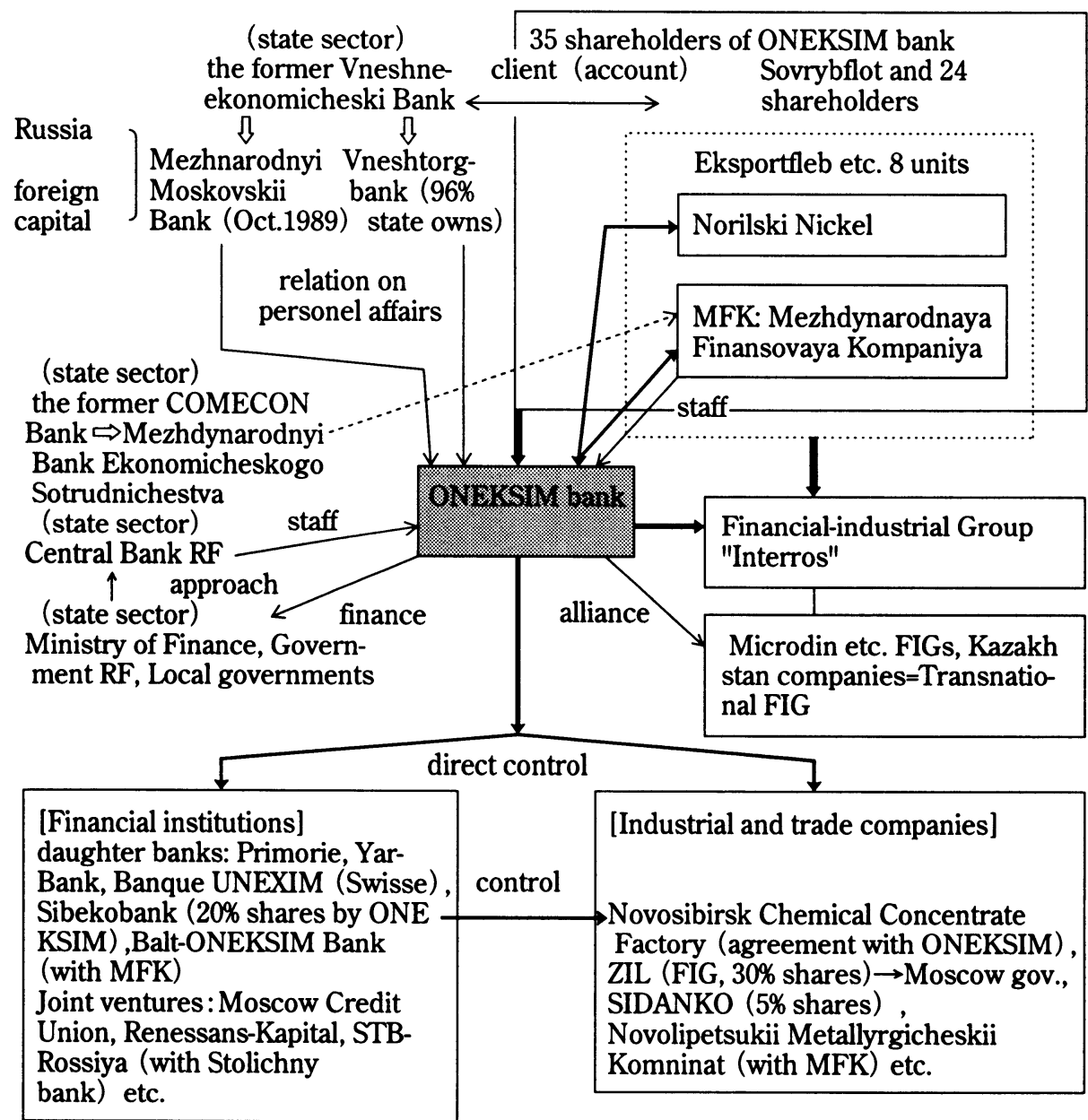

$\Rightarrow$ : reorganization, succession (including $\cdots \cdots . . .$.
or personel affairs, finance, etc.) $\longrightarrow$ : capital relations 
Changes in the Economic and Social Structure and Alternatives of the Economic Policy in Russia

Satoshi Mizobata

(Kyoto University, KIER)

\section{SUMMARY}

"Revival of the Communist party" reflects changes and inertia in the Russian transition since 1992. I describe the economic and social situation from the four aspects: macro economic figure, regional economy, behaviour of capital and employees, and the relationship between the state and enterprises. According to macro economic statistics, though an inflation rate has been stabilized, the real economy has experienced a sharp decline. In spite of OECD estimates of expected plus growth in 1995, GDP suffer a decline in 1996, and this negative tendency creates a pessimistic outlook. The opinion poll indicates an increase of a negative attitude toward marketisation with emerging strata adaptable to market economy. The regional economy suggests that marketisation has created winner regions and loser regions and the regional gap has enlarged.

As for capital formation, the economic elites have already been shaped and they intensified their monopolistic power which indicates not only profit-seeking but also rent-seeking. Among the economic elites, the banking sector gained a strong power by the following means. The first is privatisation by a consortium of banks holding a mortgage of state shares for privatized enterprises. Many banks have influenced management of enterprises as outsiders and enlarged their financial relations. Secondly, large financial capital has been formed through the establishment of Financial-industrial Groups (FIGs), which are supported by both the government and the Communist party. Most of FIGs were rewarded with good fruits and their power became more influential through cross holdings and reintegration within CIS countries. This group formation means that there exists a common interest among financial institutions and enterprises, and the government regards it as a locomotive of economic growth. Moreover, the behaviour of enterprises includes both changes and inertia. On the one hand, enterprises behave under profit-seeking and demandconstraints, and on the other hand they behave under paternalism and try to keep employment on the basis of assistance and subsidies from the state. Therefore, an interdependent common interest has overspread the government, capital and workers, and among interested parties the power of workers is weaker than that of capital.

The economic programmes of candidates for president were based on changes and inertia in transition. G. Zyuganov made public the programme entitled "From Destruction to Creation. Russia's Road to the 21st Century". The text criticised marketisation of Yeltsin and his government and proposed mixed economy, selective soft credits to producers guided by an industrial policy, an import substituting growth and the role of the state. Though this policy is incompatible with IMF conditions, it is based on two precedents: F. D. Roosevelt's New Deal of 1933 and the Third Way Reforms in the USSR in the 1980s, and it is regarded as quite moderate. The programme of B. Yeltsin was entitled "Russia: Human, Family, Society and State". Admitting some mistakes and good results in the economic field, he also emphasized the role of the state, an industrial policy, an export-oriented growth, and protectionism. Although he is cautious in relaxation of stabilization policy, his programme is common to the policy of Zyuganov's regarding the role of the state and the emphasis on the investment policy. This common features affect policies of the academic institu- 
tions and the government.

"Revival of the Communist party" in Russia emerges under the counterforce and promotive power for marketisation, and it depends on not eagerness for the socialist system but the pecurialities of the Russian market. The pecurialities mean the evolutional marketisation based on tradition and inertia inherent in the Russian society, poor adaptability of enterprises to market and their behaviour seeking linkage with the government, continuity in the elite strata, and the nation's distrust in politics. These pecurialities make a confrontation between both economic programmes unclear and the alternatives of the economic policy intensify the power of monopoly and elites with certainty.

Key words: changes and inertia

Financial-industrial Groups

economic elites

profit-seeking and rent-seeking

industrial policy 